\title{
Turkey red prints: identification of lead chromate, Prussian blue and logwood on Turkey red calico
}

\author{
Julie H. Wertz ${ }^{1}$ (D) \\ Anita Quye ${ }^{1, *}$ (D) \\ David France ${ }^{2}$ iD \\ ${ }^{1}$ Centre for Textile Conservation, University of Glasgow, 56 Dumbarton Road, Glasgow G11 6AQ, UK \\ ${ }^{2}$ School of Chemistry, University of Glasgow, Joseph Black Building, University Avenue, Glasgow G12 8QQ, UK \\ *anita.quye@glasgow.ac.uk
}

\begin{abstract}
In this research, printed Turkey red calico from the 19th century is analysed using conservation-based techniques to identify the materials used in their manufacture. Turkey red production was a significant industry in Scotland, and the textiles found in archives and collections are a valuable part of Scottish heritage and material history. Turkey red prints were produced via a unique dyeing process followed by discharge printing, and the analysis in this paper using SEM-EDX, FTIR, UHPLC, and microscopy confirms they were made as documented in the literature. Here, we show that lead chromate, Prussian blue, and logwood were used to create the distinctive prints. These results are useful to develop material-specific guidelines for storage and display for improved conservation and collection accessibility.
\end{abstract}

Pintados a vermelho-turco: identificação de cromato de chumbo, azul da Prússia e pau de campeche em chitas vermelho-turcas

\section{Resumo}

Nesta investigação, algodões pintados a vermelho-turco datados do século XIX são analisados através de técnicas da conservação, com vista à identificação dos materiais usados na sua manufactura. A produção de vermelho-turco foi uma indústria de significativa importância na Escócia e os têxteis encontrados hoje em dia em arquivos e colecções representam uma componente inestimável do património escocês e da história material do país. Os algodões pintados a vermelho-turco eram produzidos através de um exclusivo processo de tingimento seguido de estampagem e a sua análise através de SEM-EDX, FTIR, UHPLC e microscopia confirma que estes foram produzidos de acordo com a literatura. Neste estudo demonstramos que o cromato de chumbo, o azul da Prússia e o pau de campeche eram usados para criar estampas distintas. Estes resultados contribuem para desenvolver directrizes ao nível material para o depósito e exibição da colecção e para a sua óptima conservação e acessibilidade.

\section{Keywords}

Turkey red calico

Pigments

SEM-EDX

FTIR

UHPLC

\section{Palavras-chave}

Chitas vermelho-turcas

Pigmentos

SEM-EDX

FTIR

UHPLC 


\section{Introduction}

One of the major challenges in the display of heritage textiles is their susceptibility to degradation from light exposure and changes in humidity and temperature, especially with organic dyes. To determine the optimal conditions for storage and display, it is necessary to know what a textile is made of, and what colorants are present. Turkey red printed calico (Figure 1) was a significant industry in Scotland for about 150 years from about 1785-1936 [1], and historical pieces are found in many collections in Scotland and around the world [2], in the form of bandana handkerchiefs, quilt piecing, and garments. The term Turkey red refers to both the dyeing process and the product, a vivid red shade on cotton fabric or yarn. It was renowned for its brilliant colour and its reputed fastness to light, washing, and rubbing [1]. It was also exceptionally bleach-resistant, and it was said that a true Turkey red could resist discolouration in eau forte (dilute nitric acid) for at least fifteen minutes [3] and retained its bright colour after exposure to bleach [4]. This characteristic chemical resistance was later exploited in the process of printmaking.

Turkey red production was established in Western Europe from the Levant in the mid-18th century [5]. The method to make Turkey red requires the cotton fibres to first be imbued with oil, which was difficult to apply selectively. As a result, Turkey red could initially only be produced as a solid red colour. A method for discharge printing using a weakly acidified paste with liquid bleach was developed to create designs on Turkey red, an accomplishment typically attributed to Daniel Koechlin around 1811 [6-8]. According to Persoz, unpublished notes from Koechlin state that the discharge process had already been developed by a Scotsman at the Monteith works, in the Glasgow area [9]. This is consistent with a series of articles and letters published in The Glasgow Mechanics' Magazine in 1824; however credit for the invention is claimed separately by John Miller, George Rodger, and David Campbell, all current or former employees of Monteith [10-16]. Regardless of who developed the initial process, it was a significant step forward in the production of Turkey red.

To create discharge prints, the paste was applied using blocks or copper rollers engraved with the desired pattern, and then the fabric was exposed to the bleaching liquor of aqueous calcium hypochlorite $\left[\mathrm{Ca}(\mathrm{ClO})_{2}\right]$. The weak acid lowered the resistance of Turkey red to the bleach, and white areas would appear where the paste had been applied. This development made it possible to create Turkey red with printed patterns, but the entire fabric still had to be dyed red first. Although in theory any colour could be printed over the discharged white spaces to create multi-colour prints, the overwhelming majority of historical printed Turkey red contains red, yellow, green, blue, white, and black. Pink, effectively light red created with less aluminium mordant, is also seen.

There appears to have been some experimentation documented in certain sample pattern books [8], but most of the literature on dyeing and printing refers only to these colours. The reason for this may be the comparative fastness of Turkey red to other dyes, because the yellow, blue, and green patterns were actually created with raised, or developed, pigments rather than dyes [17-19]. Yellow was created by mixing lead nitrate $\left[\mathrm{Pb}\left(\mathrm{NO}_{3}\right)_{2}\right]$ with the acid paste and then, after discharging with bleach, developing the colour via a solution of aqueous potassium chromate $\left(\mathrm{K}_{2} \mathrm{CrO}_{4}\right)$ to precipitate lead chromate onto the fibres [20]. Blue areas were made with Prussian blue (ferric ferrocyanide) during the discharge process through a combination of potassium ferrocyanide and iron nitrate, while green was created by layering yellow and blue [19]. Black could be either Prussian blue layered over undischarged red, or logwood printed over the red at the very end [8]. In this case, the choice could have a significant impact on the display potential of the piece due to the difference in fastness between logwood and Prussian blue.

The practice of Turkey red discharge printing is documented in the literature $[6,19]$, but no analytical investigations have previously been undertaken to confirm the presence of these compounds on historical pieces. This research was part of a doctoral project on the re-creation and characterisation of the Turkey red complex at the University of Glasgow Centre for Textile Conservation and Technical Art History (CTCTAH), to understand more about these unique textiles for improved conservation and display practice. A combination of in situ analysis and sampling of fibres was done depending on the technique in question. The fibre samples were examined using polarised light microscopy and a Dino-Lite digital microscope camera. For elemental analysis of lead chromate, scanning electron microscopy with energy dispersive X-ray spectrometry (SEM-EDX) was used, and diffuse Fourier transform infrared spectroscopy (FTIR) allowed for the investigation of organic components of Prussian blue. Organic dyes were identified by ultra-high performance liquid chromatography with a photodiode array detector (UHPLC-PDA).

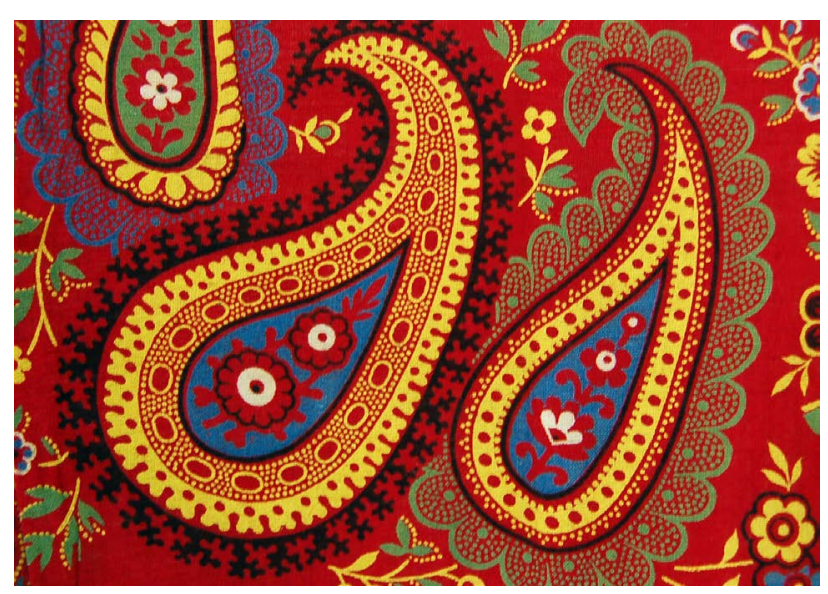

Figure 1. Printed Turkey red (1887), UGD 13/8/6. University of Glasgow Archive Services, Records of United Turkey Red Co Ltd, GB248. 


\section{Methods and samples}

Samples of coloured fibres from 19th century printed Turkey red were taken from the unfinished edges of textiles preserved in sample pattern books in the Glasgow University Scottish Business Archive. They were made by the constituent firms of the United Turkey Red Company Limited (UTR), which operated in the west of Scotland from the late 18 th to early 20 th centuries [1]. The samples analysed in this paper are shown in Table 1 with the sample number, colour, and analytical technique.

The samples were examined using polarised light microscopy. The pigments were analysed by diffuse Fourier transform infrared spectroscopy (FTIR) and scanning electron microscopy with energy dispersive X-ray spectrometry (SEM-EDX), and logwood identified by ultra-high performance liquid chromatography with a photodiode array detector (UHPLC-PDA).

\section{Polarised light microscopy}

The samples were examined using a Zeiss Axiolab Pol polarising microscope and documented with a Zeiss Axiocam 105 colour camera.

\section{SEM-EDX}

Analysis of the yellow, green and blue samples was carried out by Dr Peter Chung at the Glasgow University Imaging Spectroscopy and Analysis Centre (ISAAC) at the Glasgow University School of Geographical and Earth Sciences using a Carl Zeiss Sigma Variable Pressure Analytical Scanning Electron Microscope with Oxford Microanalysis software. The samples were situated on a carbon stub and placed in the sample chamber at $45 \mathrm{~Pa}$. Detectors for variable pressure secondary electron (VPSE), angle-selective backscatter (AsB), and energy dispersive $\mathrm{X}$-ray (EDX) were used to investigate sample surfaces, elemental distribution, and composition. The SE and AsB used an acceleration voltage of $20 \mathrm{kV}$ and the EDX used 0-20 kV depending on the required intensity of the signal.

\section{FTIR}

Analysis was done using an Agilent 4100 Handheld FTIR spectrometer with a diffuse reflectance sample interface. The sampling area was a circle approximately $0.8 \mathrm{~cm}^{2}$. Each spectrum is the average of 128 scans taken from $4000-650 \mathrm{~cm}^{-1}$ at $4 \mathrm{~cm}^{-1}$ resolution in absorbance mode, and a background of the instrument cap was taken every ten minutes. Three spectra were taken for each colour, then averaged and displayed using Spectragryph software.

\section{UHPLC-PDA}

Dyes were extracted using a two-step extraction technique suitable for a broad range of dyes [21-22].
Table 1

Samples of printed Turkey red fibres

\begin{tabular}{|c|c|c|c|}
\hline Sample & ID & Colour & Technique \\
\hline 1 & UGD 13/8/1 \#2 & Yellow & SEM-EDX \\
\hline 2 & UGD $13 / 8 / 3 \# 5$ & Green & SEM-EDX \\
\hline 3 & UGD 13/8/4 \#3 & Blue & SEM-EDX \\
\hline 4 & UGD 13/8/5 \#3 & Black & UHPLC-PDA \\
\hline 5 & UGD 13/8/8 \#9 & Green & FTIR \\
\hline 6 & UGD 13/8/8 \#10 & Blue & FTIR \\
\hline 7 & UGD 13/8/8 \#11 & Black & FTIR \\
\hline 8 & UGD 13/8/7 \#6 & Pink, black & FTIR \\
\hline 9 & UGD 13/8/5 \#9 & Black & UHPLC-PDA \\
\hline
\end{tabular}

The fibre sample was placed in a $1.0 \mathrm{~mL}$ flat-bottomed glass vial, $50 \mu \mathrm{L}$ dimethylsulfoxide (DMSO) added, and the open vial placed in a Talboys dry block heater at $80{ }^{\circ} \mathrm{C}$ for 10 minutes. The DMSO was then extracted with a micropipette and retained in a second vial. The fibre was extracted a second time with $75 \mu \mathrm{L}$ oxalic acid solution made of $0.5 \mathrm{M}$ oxalic acid/acetone/water/ methanol (1:30:40:30 v/v/v/v). The vial was returned to the block heater and left for 15 minutes at the same temperature. The oxalic acid extract was then vacuum evaporated to dryness using a BUCHI R-215 Rotavapor at $40{ }^{\circ} \mathrm{C}$ and 16 mbar for 30 minutes. The DMSO portion was returned with a micropipette to the fibre vial and the residue reconstituted to combine the extracts. This was filtered through a $0.2 \mu \mathrm{m}$ PTFE syringe filter to remove particulates and collected in a vial insert.

Sample analysis was performed on a Waters ACQUITY UPLC H-Class system at the CTCTAH. The system is comprised of a sample manager with a flow through needle, a quaternary solvent manager, a column with thermostat ability, and a PDA detector. The system was operated using Waters ACQUITY UPLC Console software and acquisition made with Waters Empower 3 software. Separation was done using a Waters C18 Ethylene Bridged Hybrid (BEH) Shield column $(150 \mathrm{~mm} \times 2.1 \mathrm{~mm}$ i. d., particle size $1.7 \mu \mathrm{m})$ with a Waters C18 BEH Shield VanGuard pre-column (5 mm x $2.1 \mathrm{~mm}$ i.d., particle size $1.7 \mu \mathrm{m})$. A gradient elution using water, methanol, and formic acid was followed [23].

\section{Results}

\section{Lead chromate}

The VPSE image of the yellow fibre (sample 1) at 2500× magnification in Figure 2 shows the pigment particles precipitated on the surface. The EDX spectrum 


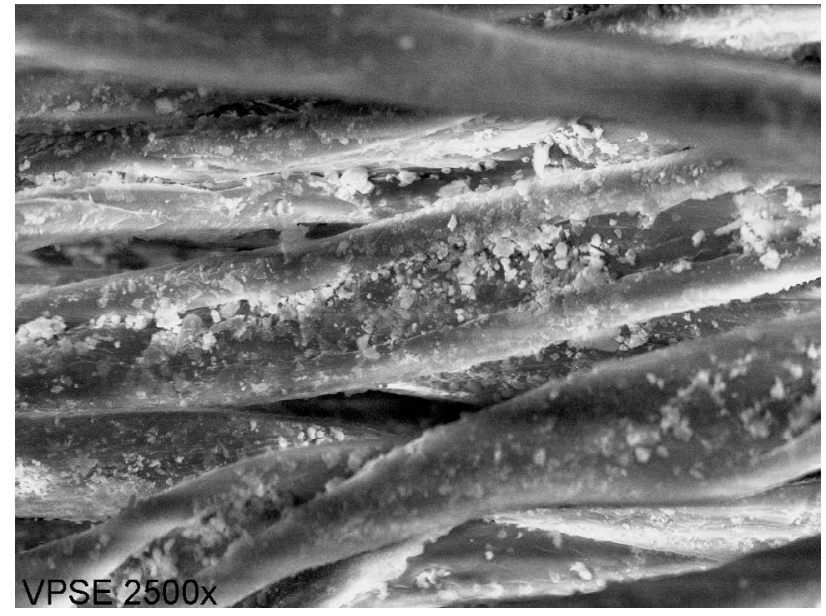

Figure 2. SEM image of yellow fibre (sample 1) showing lead chromate particles on the surface.

in Figure 3 confirms the presence of lead and chromium in the sample, confirming the yellow shade is the result of lead chromate forming during the printing process.

In the Dino-Lite image of the green fibre (sample 2) at around 200× magnification (Figure 4), the colour appears to be a stippled combination of yellow and blue that produces the green perceived by the eye with normal viewing. The AsB images at 500 $\times$ and $3500 \times$ magnification are consistent with this, showing bright patches where the lead chromate is present and less luminous areas corresponding to the Prussian blue pigment. The EDX spectrum in Figure 3 confirmed the presence of lead and chromium, as well as iron. Iron was also present on the blue sample (sample 3), but the response was much less than the lead chromate due to the relatively higher response of EDX to lead, lower concentration, or that this colour has penetrated deeper into the fibre.

\section{Prussian blue}

A polarised light microscopy image of the blue sample (sample 3) at $20 \times$ nominal magnification in Figure 5 shows the deposits of colour on the cotton fibres. Due to the minimal surface area of single fibres making FTIR analysis without a microscope difficult, the samples used for SEM-EDX could not be tested with FTIR. Samples 5-7 were analysed in situ from green, blue, and black areas on printed Turkey red in UGD 13/8/8 (Figure 6) to confirm the presence of Prussian blue.

FTIR spectra of Prussian blue have a peak from the cyano $(\mathrm{C} \equiv \mathrm{N})$ group stretching around $2080 \mathrm{~cm}^{-1}$ [24]. This peak was anticipated in the green and blue areas, but black was of special interest because the literature indicates it can be produced two ways, by layering either Prussian blue or logwood over the dyed red ground. Logwood cannot be detected by FTIR because dyes typically are in too small of a quantity to have a signal that shows above that of the bulk fibre. In samples 5-7, the cyano peak was easily distinguished in the spectra as shown in Figure 7a. A second set of spectra were taken from a pink and black textile (Figure 8, sample 8) in Figure 7b did not have a peak around $2080 \mathrm{~cm}^{-1}$, indicating that black was not made with Prussian blue and may therefore contain logwood.
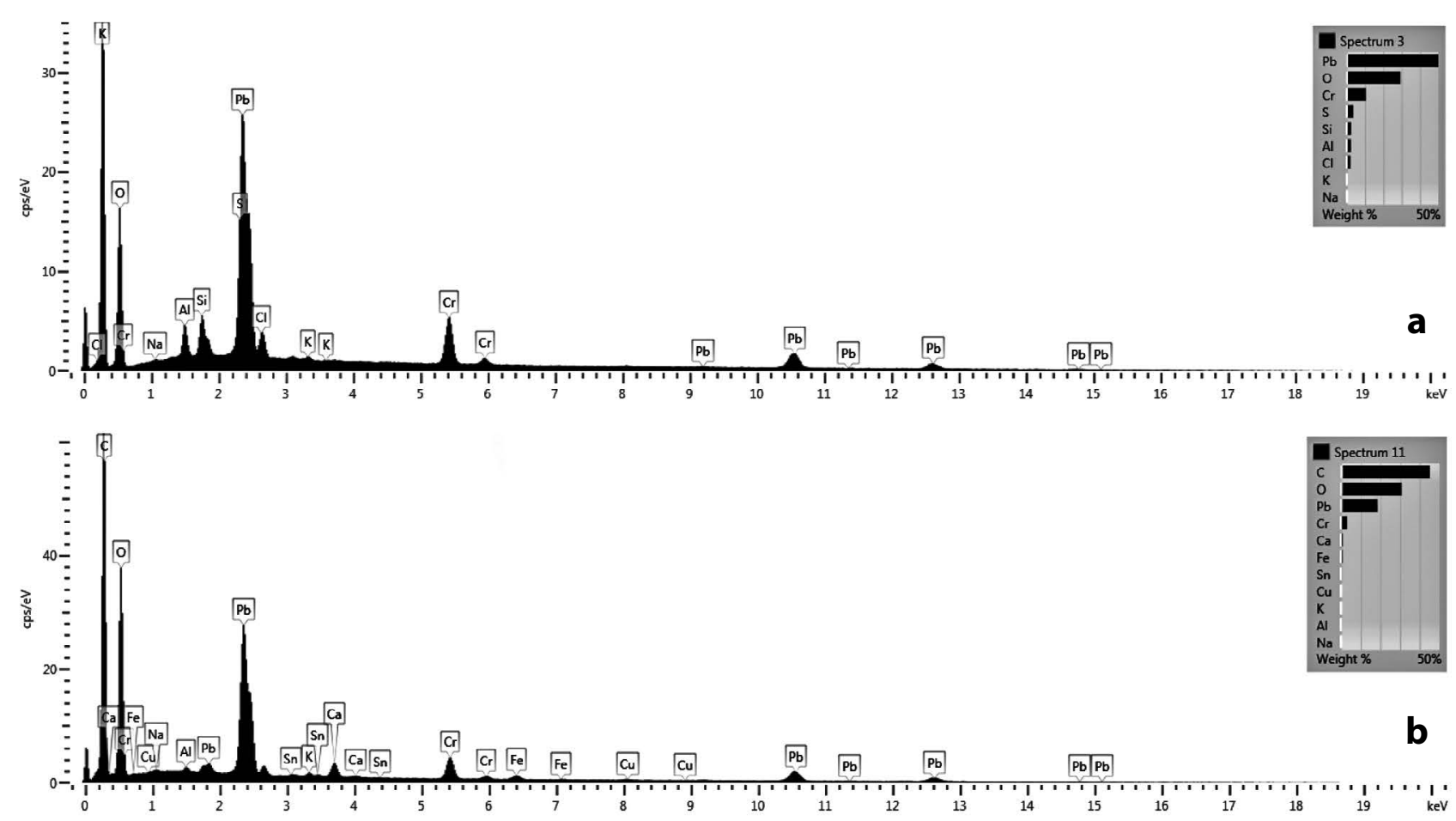

Figure 3. EDX Spectra of (a) yellow (sample 1) and (b) green (sample 2) fibres. 

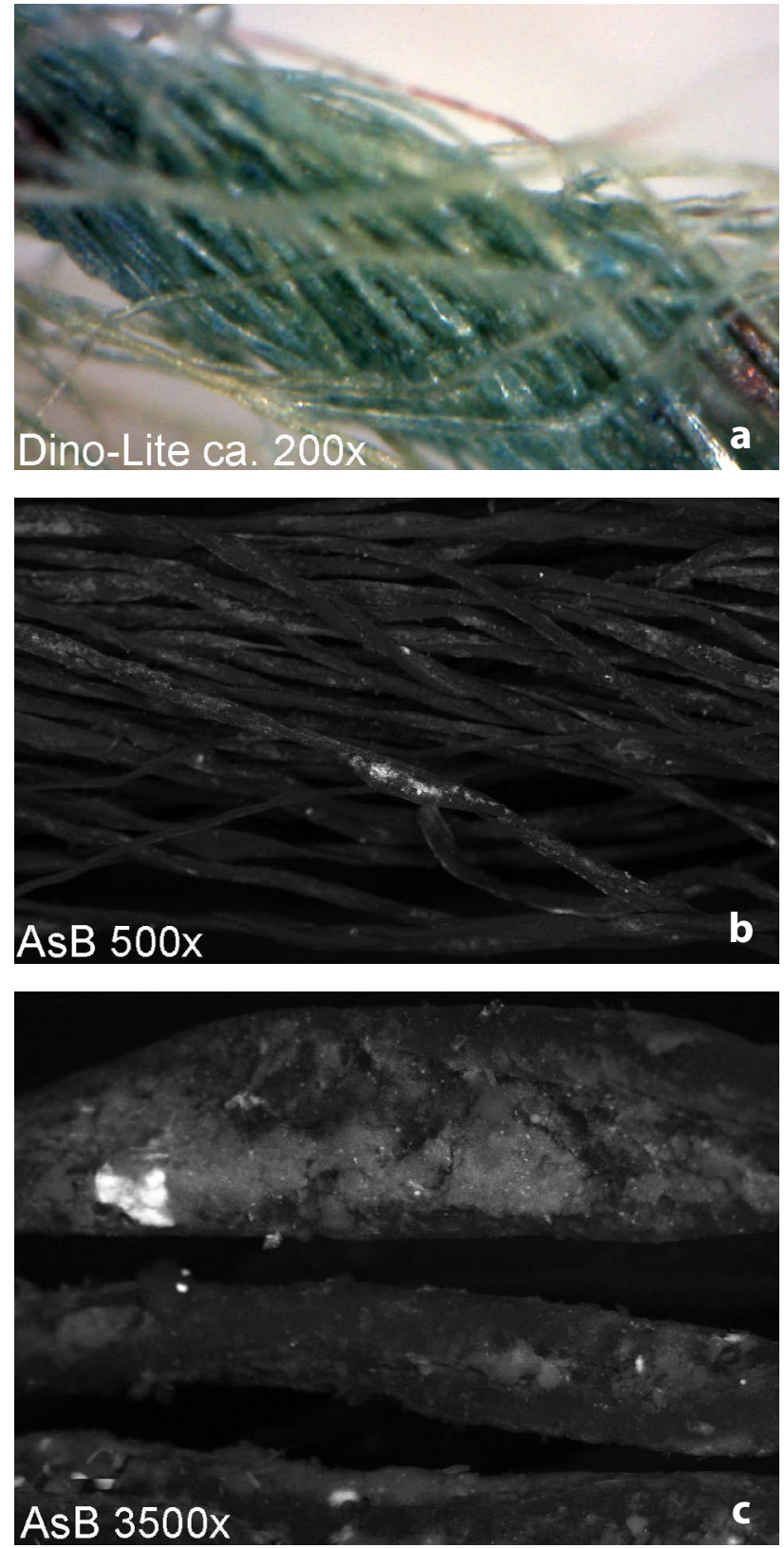

Figure 4. Dino-Lite (a) and SEM images (b, c) of green sample (sample 2) showing the lead chromate and Prussian blue deposits on the fibre.

\section{Logwood}

The analysis by UHPLC-PDA of two black fibres confirmed that the colour was printed with the two different methods, although they were taken from the same sample pattern book UGD 13/8/5. After extraction, sample 4 had lost all colour while sample 9 was now blue (Figure 9). Reference standards were not available for the two main components of logwood, haematoxylin and haematein (oxidised haematoxylin) [25]. A sample of cotton dyed with logwood was taken for comparison from A Manual of Dyeing (vol. 3, 1893) [26] in the personal collection of Anita Quye for a reference sample. Both the TR sample chromatograms contained the anticipated anthraquinone dyes, such as alizarin. The chromatograms, viewed at $350 \mathrm{~nm}$, had peaks in sample 4 consistent with the logwood reference sample that were absent in sample 9 (Figure 10).

\section{Conclusions}

The analysis of the yellow, green, blue, and black Turkey red fibres confirmed the printed textiles were made according to the processes documented in the literature. The SEM-EDX analysis identified lead and chromium on the yellow and green fibres, as well as iron on the green and blue fibres. The FTIR analysis identified Prussian blue on the green and blue areas, and also on a black area. Extraction of the dyes and analysis by UHPLCPDA confirmed that black could be produced with either Prussian blue or logwood layered over the red ground. The identification of Prussian blue by handheld diffuse FTIR is a useful, non-invasive technique for the analysis of historical Turkey red, especially in the case of the United Turkey Red collection where the textiles are mounted in large, fragile books.

The unusual Turkey red dyeing process made it necessary to use a discharge printing process to create patterns on the textiles. The robustness of Turkey red to fading, especially for light exposure and washing, meant that printed colours would have to be of comparable quality to avoid uneven wear in the finished product. The low water solubility of lead chromate and Prussian blue probably contributed to the wash fastness of the prints. Prussian blue also has a generally good lightfastness, although this has primarily been studied in the context of paintings [27]. A systematic study of cotton dyed with logwood using various metal mordants found that it had generally good wash fastness, but variable and only moderate light fastness [28]. The effect of printing, rather than dyeing, may also have further impact on its robustness since the printing process will impart less dye,

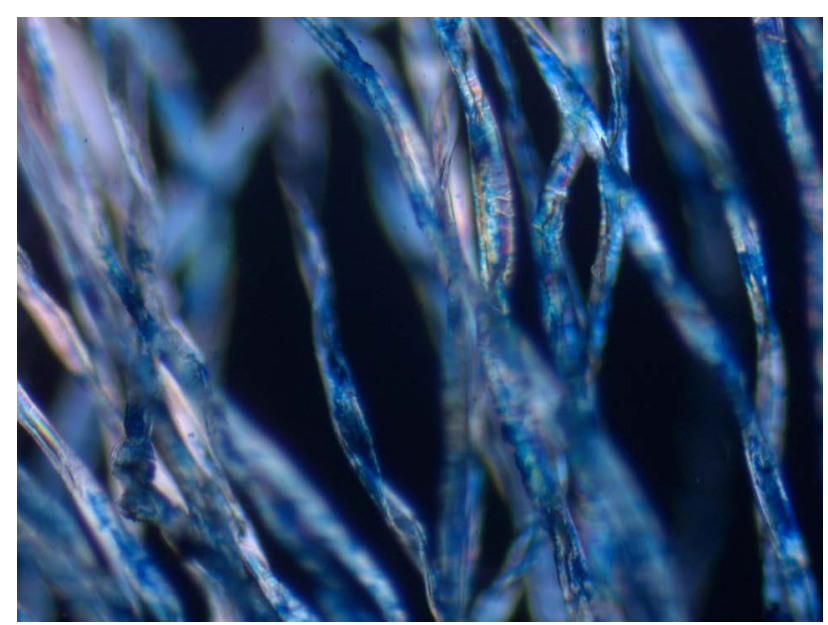

Figure 5. Polarised light microscopy image of blue fibre (sample 3). 

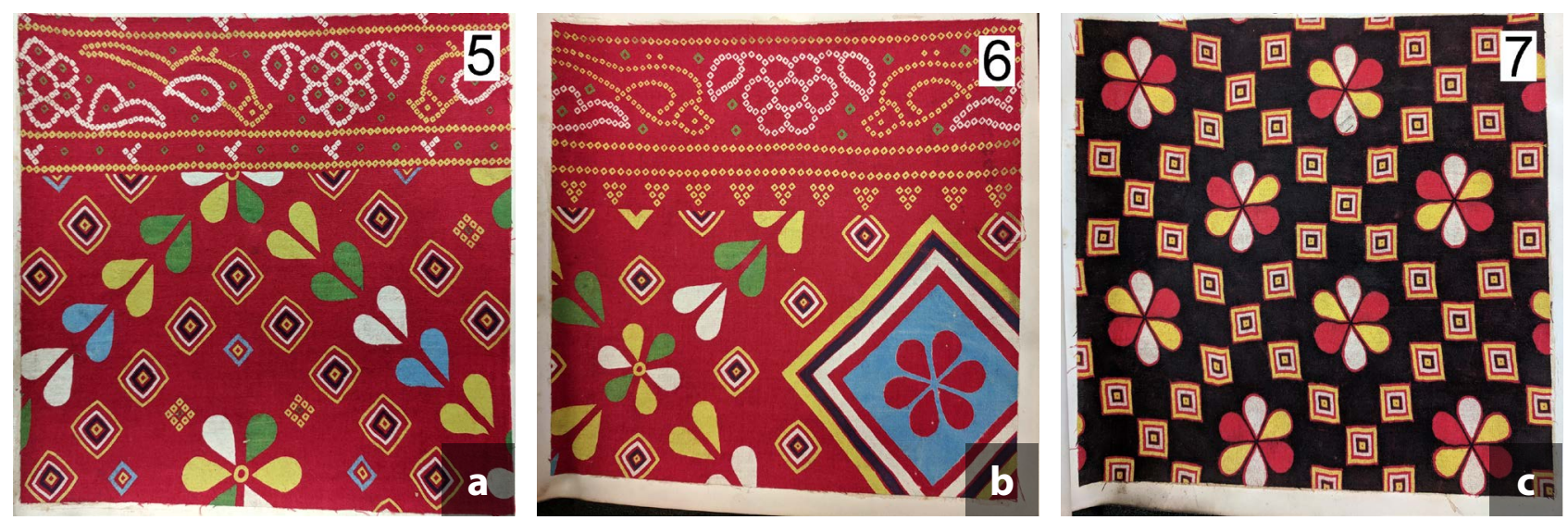

Figure 6. Printed Turkey red in UGD 13/8/8 analysed by diffuse FTIR. Spectra were taken of the green petals $(a)$, blue square $(b)$, and black ground (c) (samples 5-7). University of Glasgow Archive Services, Records of United Turkey Red Co Ltd, GB248.
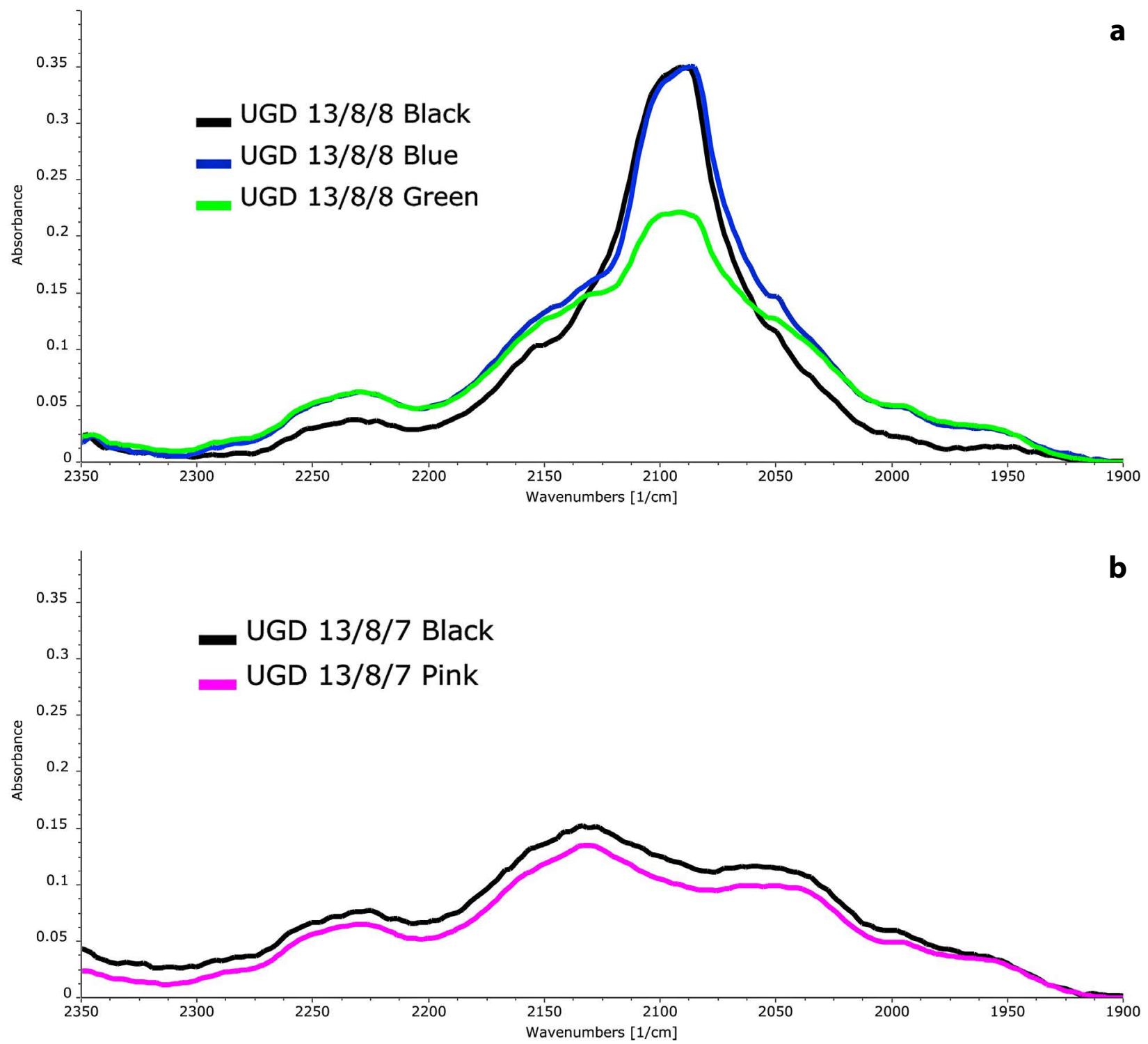

Figure 7. FTIR spectra of printed Turkey red. 


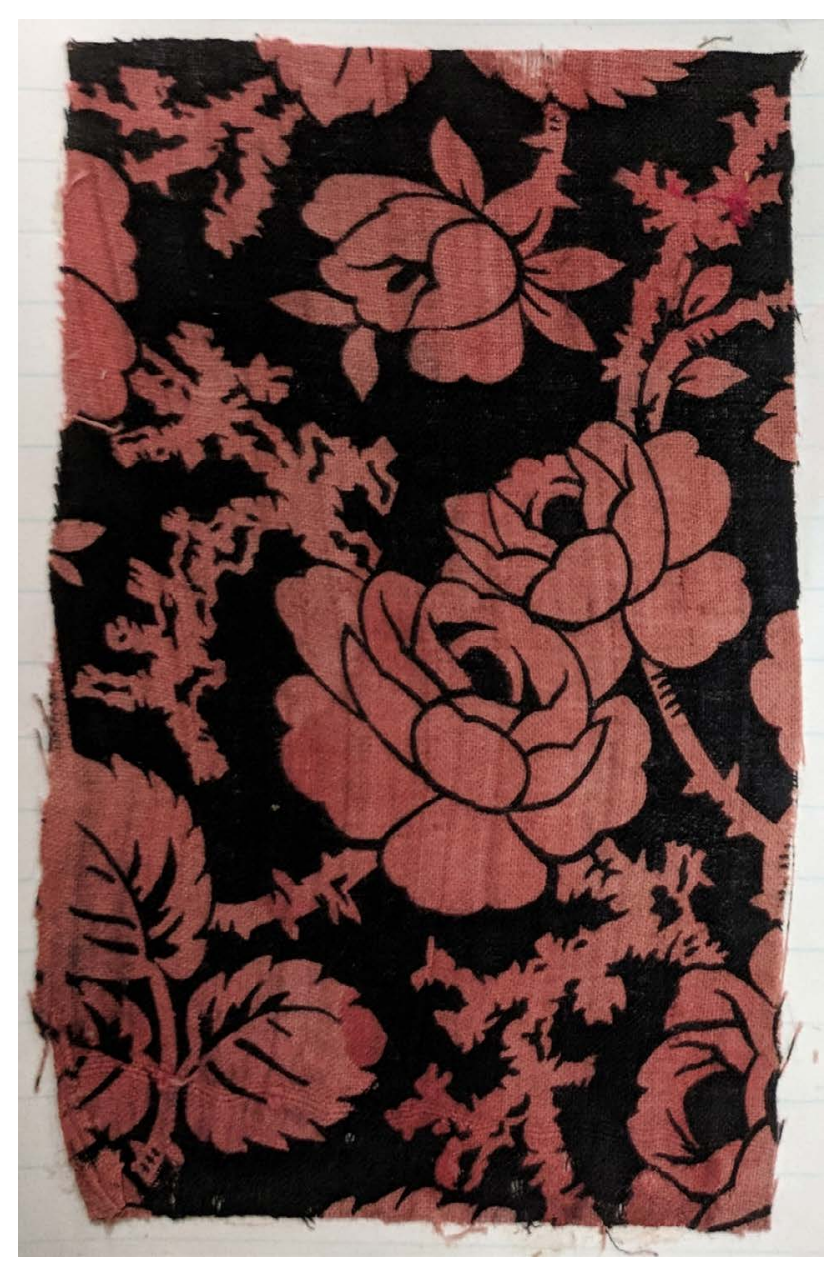

Figure 8. Printed Turkey red UGD 13/8/7 (8) analysed by diffuse FTIR. University of Glasgow Archive Services, Records of United Turkey Red Co Ltd, GB248.

and possibly by a different route, than the dyeing process. Lead chromate has been known to darken with exposure to light [29], however previous research was again on paintings rather than textile substrates. Studies of these pigments in a textile context would be useful for care and display of Turkey red collections.

The typical colourway of printed Turkey red is very consistent and indicates most prints were made using lead chromate, Prussian blue, and possibly logwood. Some exceptions can be found, and merit further research on their material composition, but in general this analysis serves as a good set of guidelines for the composition of Turkey red prints. A current project funded by an EU Marie Skłodowska-Curie Action (LightFasTR) [30] is investigating the light fastness of Turkey red, to hopefully develop light exposure guidelines for improved display practice.

\section{Acknowledgements}

This research was possible thanks to funding from the University of Glasgow Lord Kelvin Adam Smith PhD scholarship for Julie Wertz. Thanks to Peter Chung at the Glasgow University
School of Geographical \& Earth Sciences for his assistance with SEM-EDX analysis, Dr Leung Tang of Agilent Technologies for his assistance with FTIR analysis, and Ela Gorska-Wiklo and the Glasgow University Archives and Special Collections staff for collections access and sampling of the Turkey red.

\section{ORCID}

\section{Julie H. Wertz}

(iD) https://orcid.org/0000-0003-1926-2038

Anita Quye

(iD) https://orcid.org/0000-0001-6962-6018

David France

(iD) https://orcid.org/0000-0002-5409-3316

\section{References}

1 Peel, R. A., 'Turkey red dyeing in scotland its heyday and decline', Journal of the Society of Dyers and Colourists 68(12) (1952) 496-505, https://doi.org/10.1111/j.1478-4408.1952. tb02744.x.

2 Nenadic, S.; Tuckett, S., Colouring the Nation: The Turkey Red Printed Cotton Industry in Scotland c.1840-1940, NMS Enterprises Limited, Edinburgh (2013).

3 Berthollet, C. L.; Berthollet, A. B., Elements of the Art of Dyeing, Stephen Couchman, London (1791).

4 Sansone, A., 'Alizarin-red and Turkey-red dyeing and printing on cotton', Journal of the Society of Dyers and Colourists 1(8)
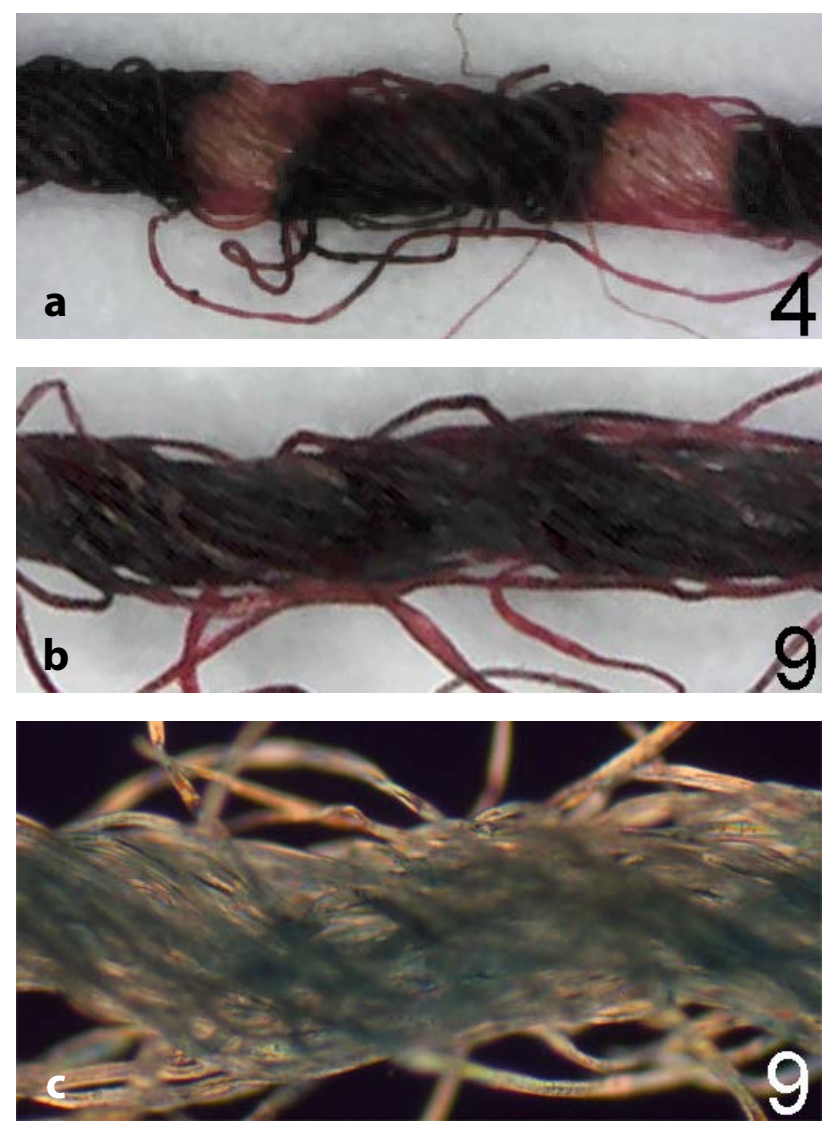

Figure 9. Samples of black fibre analysed by UHPLC-PDA before (a, b) and after (c) extraction. 


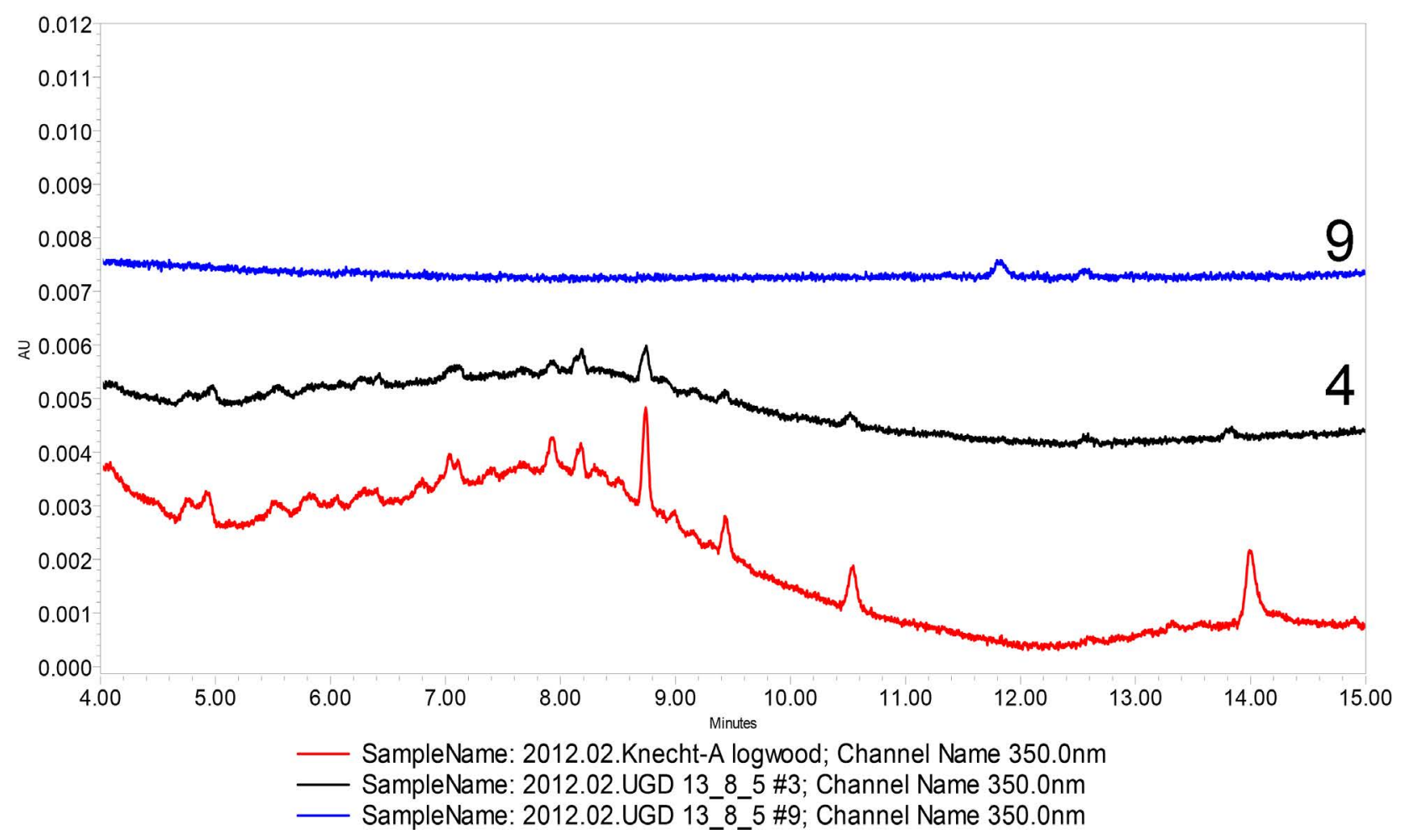

Figure 10. UHPLC chromatograms of Turkey red fibres and a logwood reference at $350 \mathrm{~nm}$.

(1885) 203-211, https://doi.org/10.1111/j.1478-4408.1885. tb00046.x.

5 Cardon, D., Natural Dyes: Sources, Tradition, Technology, and Science, Archetype Publications, London (2007).

6 Bremner, D., The Industries of Scotland, Their Rise, Progress and Present Condition, Adam and Charles Black, Edinburgh (1869).

7 Jacqué, J. (ed.), Andrinople: Le Rouge Magnifique, Éditions de La Martinière, Paris (1995).

8 Storey, J., 'Turkey red prints', Surface Design Journal 29(4) (1996), 7-9, 34-35, 38.

9 Persoz, J.-F., Traité Théorique et Pratique de l'impression des Tissus, Victor Masson, Paris (1846).

10 'On the process for discharging Turkey-red', The Glasgow Mechanics’ Magazine 1(8) (1824) 117-118.

11 'On the process for discharging Turkey-red', The Glasgow Mechanics' Magazine 1 (9) (1824) 138-140.

12 'Notices to correspondents', The Glasgow Mechanics' Magazine 1(10) (1824) 160.

13 'Discharging of Turkey-red', The Glasgow Mechanics' Magazine 1(11) (1824) 176.

14 'Notices to correspondents', The Glasgow Mechanics' Magazine 1(13) (1824) 208.

15 'Notices to correspondents', The Glasgow Mechanics' Magazine 1(14) (1824) 224.

16 Miller, J., 'Statement relative to the discharging process of Turkey red, by means of presses', The Glasgow Mechanics' Magazine 1(29) (1824) 462-464.

17 The Dyer and Colour Maker's Companion, William Mackenzie, Glasgow (1849).

18 Crookes, W., A Practical Handbook of Dyeing and CalicoPrinting, Longmans, Green and Co., London (1874).
19 Duerr, G.; Turnbull, W., Bleaching and Calico Printing: A Practical Manual, Charles Griffin \& Company, Limited, London (1896).

20 Berthollet, C. L.; Berthollet, A. B., Elements of the Art of Dyeing and Bleaching, Thomas Tegg, London (1841).

21 van Bommel, M.; Devièse, T.; Karapanagiotis, I.; Higgitt, C.; Kirby, J.; Mantzouris, D.; Peggie, D.; Proaño Gaibor, A. N.; Russell, J.; Berghe, I. V., 'To extract or not to extract: strategies for the extraction of organic colorants from textile and paint samples', comunication, Dyes in History and Archaeology 33, Glasgow (2014).

22 Han, J., 'The historical and chemical investigation of dyes for high status chinese costume and textiles of the ming and qing dynasties', PhD thesis, University of Glasgow, Glasgow (2016).

23 Serrano, A.; Van Bommel, M.; Hallett, J., 'Evaluation between ultrahigh pressure liquid chromatography and high-performance liquid chromatography analytical methods for characterizing natural dyestuffs', Journal of Chromatography A 1318 (2013) 102-111, https://doi.org/10.1016/j.chroma.2013.09.062.

24 Ghosh, S. N., 'Infrared spectra of the Prussian blue analogs', Journal of Inorganic and Nuclear Chemistry 36(11) (1974) 2465-2466, https://doi.org/10.1016/0022-1902(74)80454-9.

25 Mantzouris, D.; Karapanagiotis, I.; Valianou, L.; Panayiotou, C., 'HPLC-DAD-MS analysis of dyes identified in textiles from Mount Athos', Analytical and Bioanalytical Chemistry 399(9) (2011) 3065-3079, https://doi.org/10.1007/s00216-0114665-4.

26 Knecht, E.; Rawson, C.; Loewenthal, R., A Manual of Dyeing, Charles Griffin \& Company, Limited, London (1893).

27 Kirby, J.; Saunders, D., 'Fading and colour change of Prussian blue: methods of manufacture and the influence of extenders', National Gallery Technical Bulletin 25 (2004) 73-99. 
28 Zarkogianni, M.; Mikropoulou, E.; Varella, E.; Tsatsaroni, E., 'Colour and fastness of natural dyes: revival of traditional dyeing techniques', Coloration Technology 127(1) (2011) 1827, https://doi.org/10.1111/j.1478-4408.2010.00273.x.

29 Easthaugh, N.; Walsh, V.; Chaplin, T.; Siddall, R., The Pigment Compendium, Elsevier Science (2004).

30 'LightFasTR: Understanding the light-fastness of heritage Turkey Red textiles through modern dye chemistry and historical dyeing technology to inform sustainable display and access' (2017), in CORDIS, European Commission, https:// cordis.europa.eu/project/rcn/207842_en.html (accessed 2019-1-26).

Received: $2018-6-12$

Revised: 2018-10-28

Accepted: 2018-10-31

Online: $2019-2-3$

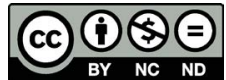

This work is licensed under the Creative Commons Attribution-NonCommercial-NoDerivatives 4.0 International License. To view a copy of this license, visit http://creativecommons.org/licenses/by-nc-nd/4.0/deed.en. 